\title{
zoosystema
}

"OUR PLANET REVIEWED" 2015

LARGE-SCALE BIOTIC SURVEY IN MITARAKA, FRENCH GUIANA Edited by Julien TOUROULT

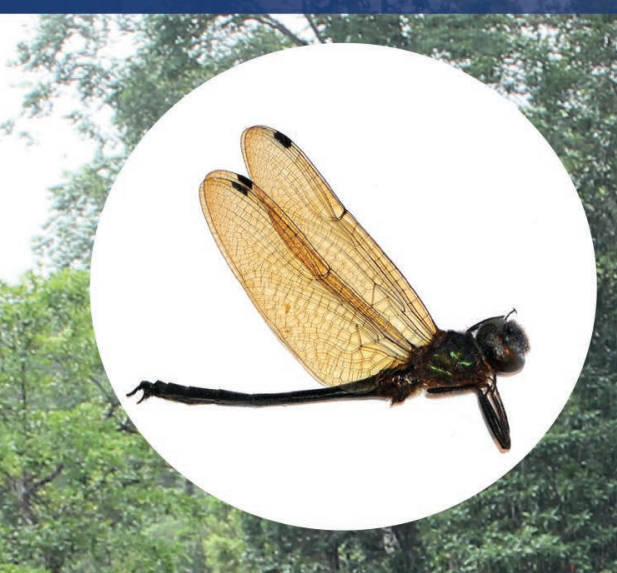

The genus Navicordulia Machado \& Costa, 1995 (Insecta, Odonata, Cordulfidae s.str.): new species, identification key for males - ahd data on ecology and distribution

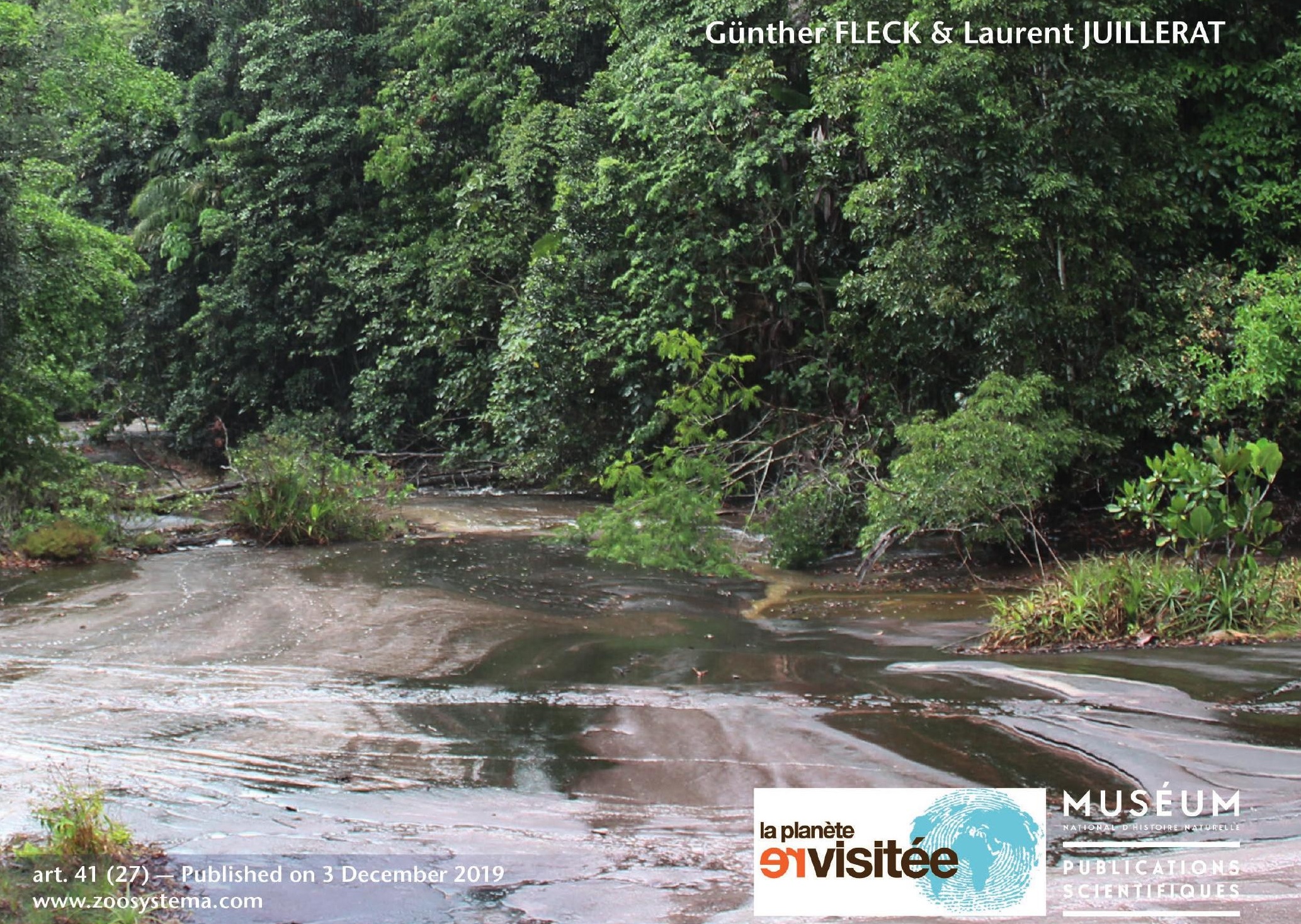

art. 41 (27) . Published on 3 December 2019

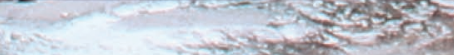

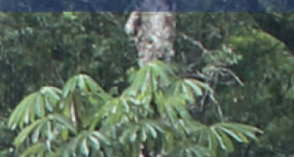

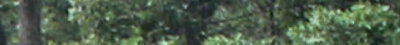


DiRECTEUR DE LA PUBlication: Bruno David

Président du Muséum national d'Histoire naturelle

RÉDACTRICE EN CHEF / EDITOR-IN-CHIEF : Laure Desutter-Grandcolas

AssistantS DE RÉDACTION / AsSISTANT EDITORS: Anne Mabille (zoosyst@mnhn.fr), Emmanuel Côtez

Mise en PAge / PAgE LAYOUt: Anne Mabille

COMITÉ SCIENTIFIQUE / SCIENTIFIC BOARD:

James Carpenter (AMNH, New York, États-Unis)

Maria Marta Cigliano (Museo de La Plata, La Plata, Argentine)

Henrik Enghoff (NHMD, Copenhague, Danemark)

Rafael Marquez (CSIC, Madrid, Espagne)

Peter Ng (University of Singapore)

Norman I. Platnick (AMNH, New York, États-Unis)

Jean-Yves Rasplus (INRA, Montferrier-sur-Lez, France)

Jean-François Silvain (IRD, Gif-sur-Yvette, France)

Wanda M. Weiner (Polish Academy of Sciences, Cracovie, Pologne)

John Wenzel (The Ohio State University, Columbus, États-Unis)

COUVERTURE / COVER:

Rock-bottomed stream near locus typicus, Barruol Mounts, Mitaraka. Photo by Stéphane Brûlé. In medaillon, general habitus of Navicordulia pascali n. sp.

Zoosystema est indexé dans / Zoosystema is indexed in:

- Science Citation Index Expanded (SciSearch ${ }^{\circledR}$ )

- ISI Alerting Services ${ }^{\circledR}$

- Current Contents ${ }^{\circledR}$ / Agriculture, Biology, and Environmental Sciences ${ }^{\circledR}$

- Scopus ${ }^{\circledR}$

Zoosystema est distribué en version électronique par / Zoosystema is distributed electronically by:

- BioOne ${ }^{\circledR}$ (http://www.bioone.org)

Les articles ainsi que les nouveautés nomenclaturales publiés dans Zoosystema sont référencés par / Articles and nomenclatural novelties published in Zoosystema are referenced by:

- ZooBank ${ }^{\circledR}$ (http://zoobank.org)

Zoosystema est une revue en flux continu publiée par les Publications scientifiques du Muséum, Paris / Zoosystema is a fast track journal published by the Museum Science Press, Paris

Les Publications scientifiques du Muséum publient aussi / The Museum Science Press also publish:

Adansonia, Geodiversitas, Anthropozoologica, European Journal of Taxonomy, Naturae, Cryptogamie sous-sections Algologie, Bryologie, Mycologie.

Diffusion - Publications scientifiques Muséum national d'Histoire naturelle

CP 41 - 57 rue Cuvier F-75231 Paris cedex 05 (France)

Tél. : 33 (0)1 40794805 / Fax: 33 (0)1 40793840

diff.pub@mnhn.fr / http://sciencepress.mnhn.fr

(C) Publications scientifiques du Muséum national d'Histoire naturelle, Paris, 2019

ISSN (imprimé / print): 1280-9551/ ISSN (électronique / electronic): 1638-9387 


\section{The genus Navicordulia Machado \& Costa, 1995 (Insecta, Odonata, Corduliidae s.str.): new species, identification key for males and data on ecology and distribution}

Günther FLECK

Entomologiste indépendant

F-07150 Lagorce (France)

fleckgunther@gmail.com

Laurent JUILLERAT

Biologiste indépendant

25 rue du Seu, CH-2054 Chézard-St-Martin (Suisse)

juillerat.l@bluewin.ch

Submitted on 1 December 2017 | Accepted on 15 October 2019 | Published on 3 December 2019

urn:Isid:zoobank.org:pub:001A5291-3130-49A9-89F5-322B140E5A55

Fleck G. \& Juillerat L. 2019. - The genus Navicordulia Machado \& Costa, 1995 (Insecta: Odonata: Corduliidae s.str.): new species, identification key for males and data on ecology and distribution, in Touroult J. (ed.), "Our Planet Reviewed" 2015 large-scale biotic survey in Mitaraka, French Guiana. Zoosystema 41 (27): 553-565. https://doi.org/10.5252/ zoosystema2019v41a27. http://zoosystema.com/41/27

KEY WORDS

Anisoptera,

Mitaraka,

phylogeny,

speciation,

canopy,

new species.

MOTS CLÉS

Anisoptera,

Mitaraka,

phylogénie,

spéciation,

espèce nouvelle.

\section{ABSTRACT}

Based on male specimens a new species of the genus Navicordulia Machado \& Costa, 1995 is described from South French Guiana. This is the second species of the genus recorded for this country. The male of Navicordulia pascali n. sp. can be easily separated from all known males of the other species of the genus by the presence of a remarkable large ventral tooth at the base of the cerci. Navicordulia pascali n. sp. is a forest dwelling species inhabiting hilly landscape at low altitude. Adults seem to be on flight during the rainy season. The new species is most closely related to N. errans (Calvert, 1909) and N. leptostyla Machado \& Costa, 1995, both from Cerrado of central Brazil. Affinities with the Venezuelan lowland N. vagans (De Marmels, 1989) are also probable. A differential diagnosis is given, and a key for Navicordulia species based on male characters is provided. The distributions are also given for all species of the genus. Aspects of ecology and biogeography are discussed.

\section{RÉSUMÉ}

Le genre Navicordulia Machado \& Costa, 1995 (Insecta, Odonata, Corduliidae s.str.) : nouvelle espèce, clé d'identification des mâles, et données sur l'écologie et la répartition.

Une nouvelle espèce du genre Navicordulia Machado \& Costa, 1995 est décrite du sud de la Guyane sur la base de spécimens mâles. C'est la seconde espèce du genre signalée de cette région. Le mâle de Navicordulia pascali n. sp. peut être aisément distingué de ceux connus des autres espèces du genre par la présence remarquable d'une grande dent ventrale à la base des cerques. Navicordulia pascali n. sp. est une espèce forestière, habitant un paysage collinéen de basse altitude. La période de vol des adultes semble coïncider avec la saison des pluies. La nouvelle espèce est apparentée à $N$. errans (Calvert, 1909) et $N$. leptostyla Machado \& Costa, 1995, deux espèces du Cerrado du centre du Brésil. Des affinités avec $N$. vagans (De Marmels, 1989), une espèce des plaines du Venezuela, sont également probables. Une diagnose différentielle est fournie, de même qu'une clé des espèces du genre basée sur les caractères des mâles. La distribution des espèces du genre est également donnée. Certains éléments d'écologie et de biogéographie sont discutés. 


\section{INTRODUCTION}

Navicordulia Machado \& Costa, 1995 is the second largest Neotropical genus of Corduliidae s.l. with 12 species. However, its erection and diagnosis are relatively recent (Machado \& Costa 1995). Most species live in forests and are very rarely encountered, being only known by the type series. Until recently the genus was only recorded from Brazil and Venezuela. During the expedition "Our Planet reviewed" in Mitaraka (Touroult et al. 2018) one species was recently discovered in French Guiana (Fleck 2017), separated by more than $1100 \mathrm{~km}$ from the closest previously described species. Here is described a 13th Navicordulia species, the second from French Guiana. This species, with one male specimen collected in Mitaraka during the expedition "Our Planet reviewed", was already mentioned but not described in Fleck (2017).

\section{MATERIAL AND METHODS}

The terminology of specific structures of Navicordulia comes from Machado \& Costa (1995). The wing terminology follows that of Bechly (1996) amended by Fleck \& Nel (2003) and Fleck et al. (2003).

Specimens were put in tepid water for $15 \mathrm{~min}$ (air dried holotype) and $30 \mathrm{~min}$ ( $95^{\circ}$ ethanol preserved paratype) before penis dissection in order to soften the cuticle. After dissection the holotype was air dried again and the paratype stored again in $95^{\circ}$ ethanol. The dissected penis are stored in microvials filled with $70^{\circ}$ ethanol.

The drawings were made using a stereoscope MZ8 with camera lucida and the photographs were taken using an Olympus TG-4 and a Keyence VHX-2000.

\section{ABBREVIATIONS}

$\begin{array}{ll}\text { S1-S10 } & \text { abdominal segments } 1 \text { to } 10 ; \\ \text { FW } & \text { forewing; } \\ \text { HW } & \text { hindwing. }\end{array}$

\section{Institutions}

MHNN Muséum d'Histoire naturelle de Neuchâtel;

MNHN Muséum national d'Histoire naturelle, Paris.

\section{RESULTS}

Order ODONATA Fabricius, 1793

Family CORDUliIDAE Selys, 1871

Genus Navicordulia Machado \& Costa, 1995

Navicordulia pascali n. sp. (Figs 1-4)

\section{urn:Isid:zoobank.org:act:B097AFD1-A942-4829-9AEA-FDAE462979DD}

MATeRial EXAmined. - Holotype. ơ, French Guiana, Cayenne Pro-

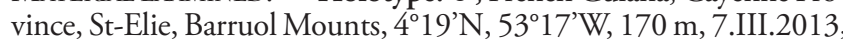
at light trap, P.-H. Dalens, S. Fernandez \& S. Brûlé leg., MHNN. Paratype. $0^{\prime \prime}$, French Guiana, Maripasoula/Mitaraka, $2^{\circ} 14^{\prime} \mathrm{N}$, 54²7’W, 320 m, SLAM, 15.III.2015, "La Planète Revisitée, Guyane
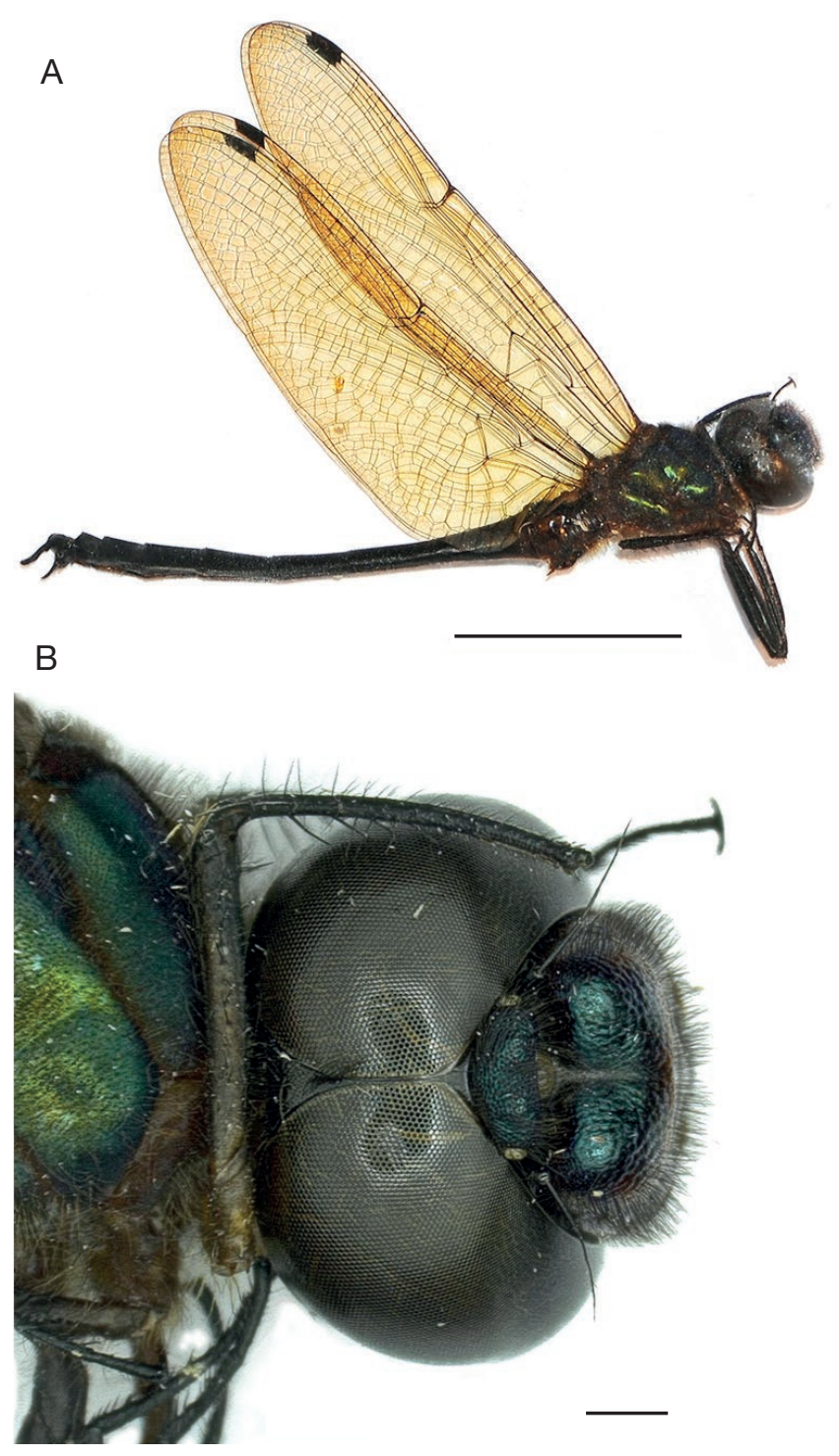

FIG. 1. - Navicordulia pascali n. sp., holotype: A, general habitus; $\mathbf{B}$, head in dorsal view and part of thorax in right lateral view. Scale bars: $A, 10 \mathrm{~mm} ; \mathrm{B}, 1 \mathrm{~mm}$.

2015” expedition, MNHN PNI, APA 973-1, canopy interception trap label MI-15-0629-03, MNHN.

Etymology. - This new species is dedicated to Mr Olivier Pascal, head and responsible of the expedition "Our Planet Reviewed Guyane-2015", during which the paratype was collected. The first author is grateful for the kind invitation to participate in this expedition.

\section{DESCRIPTION}

Holotype

State of preservation. Very good. Only a few cells at apex of the left FW are missing, and S7-9 are artificially slightly laterally compressed.

Body. Medium-sized dragonfly. Head and thorax hairy. Body with metallic reflections, blackish abdomen and lacking citron-yellow markings (Fig. 1A). 

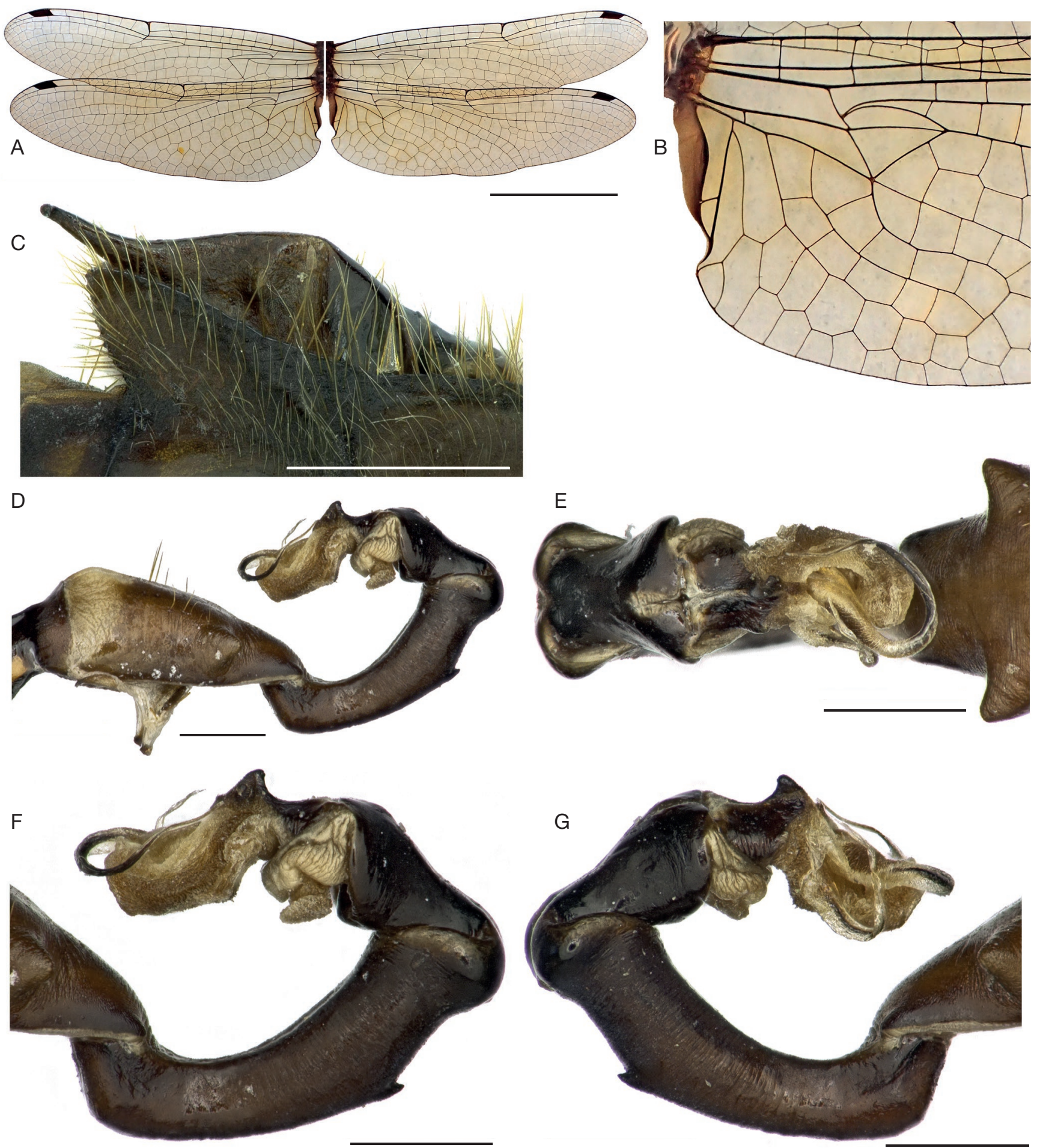

FIG. 2. - Navicordulia pascali n. sp., holotype: A, wings in ventral view; B, base of left HW in ventral view; C, S2 secondary genitalia in left lateral view; D, vesica spermalis in left lateral view (removed from ethanol and air dried); $\mathbf{E}$, distal segments of the vesica spermalis in left lateral view (removed from ethanol and air dried); F, distal segments of the Vesica spermalis in right lateral view (removed from ethanol and air dried); G, distal part of the first segment and distal segments of the vesica spermalis in ventral view (removed from ethanol and air dried). Scale bars: A, $10 \mathrm{~mm}$; B, D-G, $0.5 \mathrm{~mm}$; C, $1 \mathrm{~mm}$.

Head. Face, frons, vertex and occiput covered by strong black hair-like setae (Fig. 1B). Labium light brown yellowish, labrum light brownish orange, clypeus brownish orange, frons with lower margin light brownish orange and with upper and dorsal parts with strong green to bluish metallic reflections (depending of light incidence, Fig. 2). Vertex dark brown with green metallic reflections, slightly flattened due to the presence of two very low tubercles. Antennae dark brown with long flagellum. Eyes in contact over a rather long distance dorsally of c. $0.9 \mathrm{~mm}$ (Fig. 1B). Posterolateral margin of eyes with a small indentation (often encountered in corduliids). Occiput dark brown. 

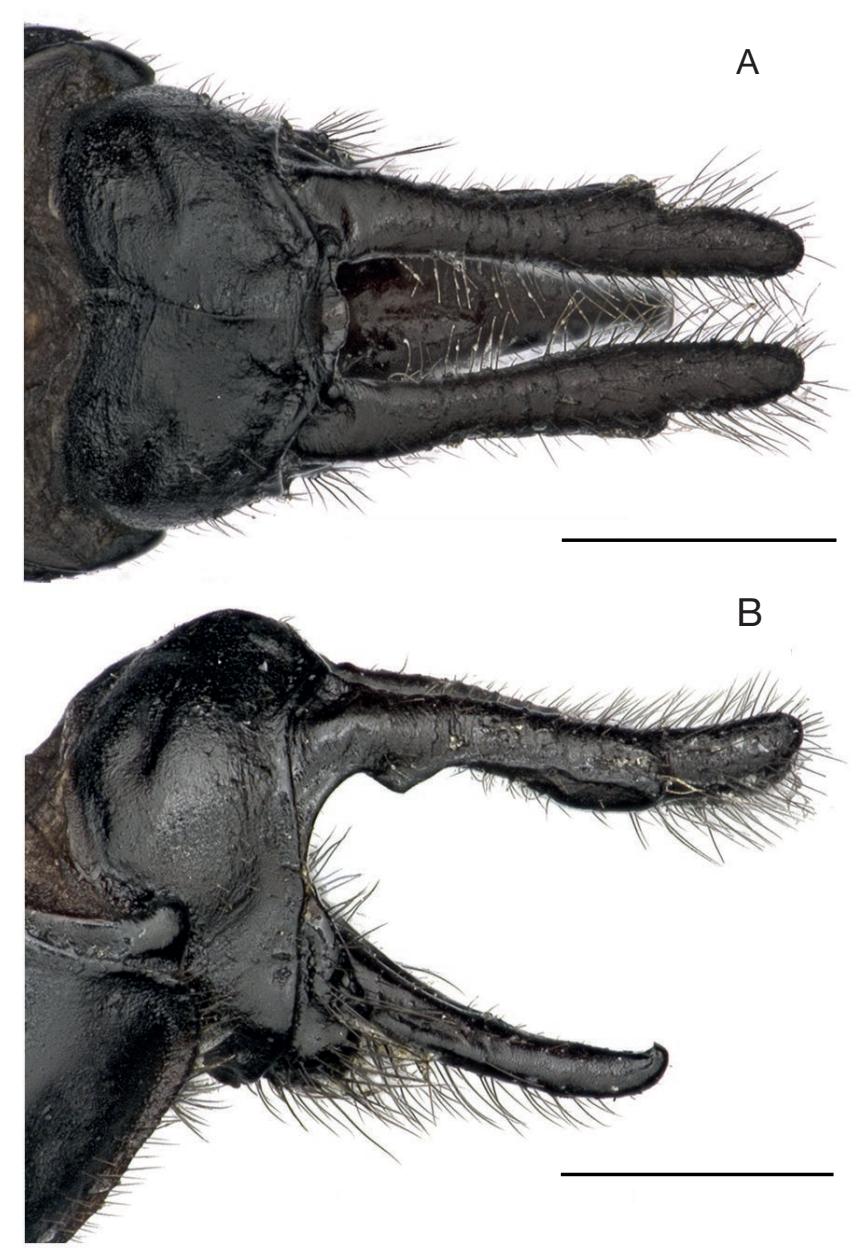

FIG. 3. - Navicordulia pascali n. sp., holotype: A, S10 and anal appendages in dorsal view; B, part of S9, S10 and anal appendages in left lateral view. Scale bars: $1 \mathrm{~mm}$.

Thorax. Covered by pale hair-like setae (Fig. 1B). Legs relatively long compared to body dimension, hind-leg being distinctly longer than the half of the HW (c. 59\%) and distinctly longer than the half of the abdomen excluding anal appendages (c. 65\%). Legs with tibiae dark brown to blackish, tarsomeres blackish and tarsal claws dark brown; profemora light brown with apical half turning gradually dark brown (Fig. 1B), mesofemora mainly blackish/dark brown with about basal $1 / 4$ brown, metafemora blackish/dark brown. Mesotrochanter with a lateral row of eight blunt small spines, metatrochanter with reduced similar row with only three or four smaller spines. Tibial keels present on prothoracic and metathoracic legs and occupying respectively $25-26 \%$ and $83-85 \%$ of the tibiae. Ventral tooth of tarsal claws well developed and situated at about $3 / 5$ of claw. Prothorax light brown to yellowish, with posterodorsal rounded margin covered by a fringe of rather long hair-like setae; no tergal process sensu Pinto \& Lamas (2010) visible. Synthorax brown with strong green metallic reflections and some copper reflections depending of light incidence (Fig. 1A, B).
Wings (Fig. 2A, B). Light saffron tinged; veins black to dark brown; membranulae well developed, brown; pterostigmata dark brown, with proximal and distal margins almost parallel, distal margin being slightly more oblique than proximal one (angular difference c. $20^{\circ}$ in FW and $10^{\circ}$ in HW); FW nodus moderately shifted distally with base-nodus ratio 0.54 (see Machado \& Costa, 1995); FW antenodal crossveins 10 of the first rank (between $\mathrm{C}$ and $\mathrm{ScP}$ ) and 9-10 of the second rank (between ScP and R); four basal and four distal FW antenodals of the first rank aligned or sub-aligned with those of the second rank but only Ax1 and Ax 2 distinctly reinforced and bracket-like; gap separating $A x 1$ and $A x 2$ distinctly more important than gaps separating other antenodals; HW antenodals 6 (first rank) +6 (second rank) with those of first rank and those of second well aligned, reinforced and bracketlike, the reinforcement diminishing distally; FW postnodal crossveins 6-8; HW postnodal crossveins 8; crossveins distal to pterostigma 2-3 (2 on left HW); base of pseudo-IR1 distinctly distal to Pt in FW and below Pt in HW; base of the sectors of arculus slightly proximal to Ax2 in FW and HW; sectors of arculus very shortly united in FW and HW; bridges with only one crossvein, this one placed distal to subnodal transverse; all hypertriangles and discoidal triangles free; FW subtriangles elongated and 2-celled; no HW subtriangles (submedian space crossed only by basal CuP between anal triangle and anal loop); position of antero-proximal angle of HW discoidal triangle shortly but distinctly proximal to posterior crossvein of arculus; Rspl rather well defined, with concavity distinct but vein somewhat zigzagged and covering one row of 5-6 cells on FW and HW; Mspl rather poorly defined in FW and covering one row of 4 cells; Mspl weak in HW and covering one row of about 4 cells; FW discoidal field with two rows of cells except at posterior wing margin (3 cells) and with MA and MP grossly parallel up to distal part of Mspl, distally very slightly convergent; anal loop with 11-13 cells and distinct midrib; anal loop with 2 cells at submedian space margin, distally not dilated, thus without distinct toe and with sole ( $\mathrm{CuAb})$ made by 2 cells; anal loop and posterior wing margin separated by 2 rows of cells throughout; anal triangle well defined, rather well elongated and 2-celled; typical generic strong anal triangle excavation; anal angle strongly marked.

Abdomen. Slender but distinctly club-shaped distally in dorsal view, slightly longer than HW, brown on S1-2 and anterior part of S3, progressively turning black on S3, black on S410. Longitudinal ventral membranes and adjacent carinae on S7-9 brown to yellowish. Green and purple metallic light gloss on dorsal S2-5, hardly visible metallic purple gloss on dorsal S6-7 and faintly visible green metallic gloss on dorsal S8-9. In lateral view abdomen swollen at S2 and anterior part of S3, narrowing from $\mathrm{S} 3$ to anterior half of $\mathrm{S} 5$, then slightly expanding again from distal half of S6 to S9 (Fig. 1A); in dorsal view constricting on S3, expanding progressively from distal S4 to posterior margin of $S 7$, then constricting again at $S$ 9. Lateral carina extending from distal $2 / 3$ of $S 4$ to $S 8$, inconspicuous on $S 4$ and progressively better marked from $S 4$ to S8. Dorsal 

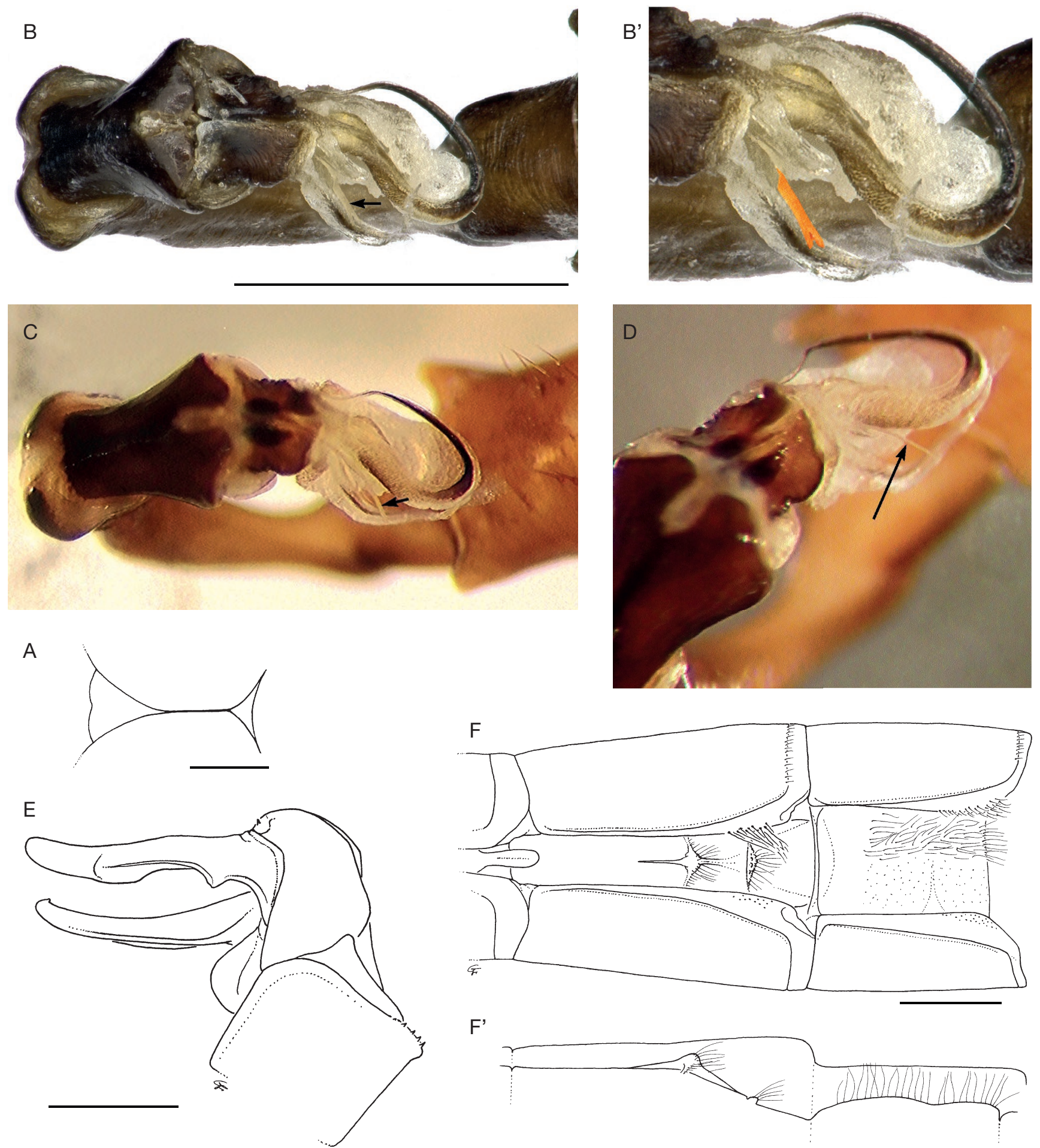

FIG. 4. - Navicordulia pascali n. sp., paratype: A, top of the head showing the eyes seam; B, vesica spermalis in ventral view (removed from ethanol and air dried): distal part of the first segment and distal segments; arrow indicates the third flagellum; B', detail of same with artificially colored third flagellum; C, vesica spermalis in ventral view with a slight lateral component (in ethanol). Arrow indicates the third flagellum; $\mathbf{D}$, distal part of the vesica spermalis in ventral view (in ethanol). Arrow indicates the third flagellum; E, S9, S10 and anal appendages in right lateral view; F, S7 and S8 pilose complex: ventral view; F' schematic longitudinal cut (lateral view, ventral part above). Scale bars: A, B, E, F, $1 \mathrm{~mm}$.

carina weak to absent, except on S10, where it appears as a small crest. S1-4 and S10 oval or subcylindrical in cross section, and S5-9 hemicylindrical in cross section due to flattened ventral side; anterior lamina and hamule of secondary accessory genitalia similar to those found in other species (Fig. 2C). S2 tergal ventral margin bearing anteriorly a dense fringe of long and strong setae and delimiting distally a triangular genital lobe caudad directed (Fig. 2C). Vesica spermalis (Figs 2D-G) 
on the whole similar to that of the other species; V4 median flagellum stronger, much strongly sclerotized and distinctly longer than lateral flagellum and therefore vesica spermalis close to the type B of Machado \& Costa (1995); sclerotized part of V4 ending as a distinct and well erected distal horn (see Pfau 2011); no trace of a third small flagellum (see below). Pilose complex of S7 mostly hidden but visible parts identical to those of paratype (see below). Pilose complex of S8 comparable to those of other species (see Machado \& Costa 1995) with an anterior glabrous area occupying the proximal $2 / 10$ of the sternite continued by a field of long, fine, straight and ventrally directed setae extending from proximal 2/10 of sternite to its posterior margin; longest setae of this field situated close to lateral margins of proximal 2/10 to $4 / 10$ of sternite (cf. Fig. 4F). Cerci (superior anal appendages) blackish/dark brown, rather short, about as long as $S 9+10$, grossly club-shaped with in dorsal view a thinner anterior part extending from base to about distal $4 / 10$ of cercus length and a posterior part larger and with rounded apex (Fig. 3A). Cerci in dorsal view well separated at base, slightly convergent from base to about proximal $6 / 10$, and almost parallel from proximal $6 / 10$ to apex (Fig. 3A). Cerci with a smooth and small dorsal tubercle close to inner margin and in contact with $S 10$, with strong basal ventral tooth situated at distal $2 / 10$, and with well-developed lateral tubercle sensu Machado \& Costa (1995) situated at distal 7/10 (Fig. 3); presence of a low ventral elongated bulging devoid of setae (ventro-medial tubercle?) extending from about $5 / 10$ to near the level of lateral tubercle at distal 7/10 (Fig. 3B). Cerci with two strong lateral carinae, the proximal one extending from base of cercus to proximal base of ventral tooth, and the second one starting from near ventral apex of ventral tooth and ending close to lateral tubercle after short attenuation (Fig. 3B, cf. also Fig. 4E); presence of a weak and short ventro-medial carina extending from the level of distal part of ventral tooth (but not connected to this structure) to the base of the ventral bulging (thus extending of about $1.5 / 10$ of the cercus length). In lateral view, transition from anterior concave part to posterior convex part of ventral margin of cerci situated distinctly proximal to lateral tubercle/distal end of second lateral carina (Fig. 3B). Distal half of cerci without dense brush of long setae (pilosity made by regularly distributed setae) (Fig. 3). Epiproct (inferior anal appendage) about $3 / 4$ length of cerci, blackish to dark brown, thin and triangular in ventral or dorsal view and with apical margin shortly truncated, slightly bilobed due to tip curved upwards, and forming a short acute ridge (Fig. 3).

Holotype measurements $(\mathrm{mm})$. Total length (including anal appendages) 40.1, eyes contact c. 0.9, FW length 26.0, HW length 25.1, FW pterostigma 1.7, HW pterostigma 1.8, pro-/meso-/metathoracic legs length (including coxa and trochanter) 10.7/12.7/15.6, metatibia length 5.6, abdomen length (including anal appendages) 29.2, superior anal appendages (cerci) 1.8, inferior anal appendage (epiproct) 1.2, abdomen width at S2 2.2, at median part of S4 (minimal width) 1.1, at posterior margin of S7/anterior margin of S8 2.3 (maximal width) (slightly laterally compressed due to mode of preservation).
Variations in paratype and complement of description

State of preservation. Medium due to its mean of collect using a canopy interception trap with collector container filled with low salinity water (heavy rains) and, in spite of care, due to difficult transport of recipient from collecting point to base camp. Left prothoracic leg, right prothoracic tarsus, right mesothoracic tibia and tarsus and left metathoracic tarsus missing; parts distal to Pt missing or damaged in all wings; apex of right cercus broken.

Head. Frons with lower margin brownish orange and with upper and dorsal parts with strong copper to green metallic reflections (depending of light incidence). Vertex dark brown with strong green metallic and light copper reflections (depending of light incidence). Eyes in contact over a slightly shorter distance dorsally of c. $0.8 \mathrm{~mm}$ (Fig. 4A).

\section{Thorax. Metathoracic tibial keel 81-82\%.}

Wings. Distal half of left HW aberrant. General coloration hyaline with very light dirty grayish saffron tinge. FW antenodal crossveins 10 of first rank and 10 of second rank; FW antenodals of first rank aligned or sub-aligned with those of second rank except for the two more distal ones on right FW. Gap separating Ax1 and Ax2 only slightly greater than gaps separating other antenodals. FW postnodal crossveins 6. Base of sectors of arculus at level of Ax2 in FW. Mspl rather weak and poorly defined and covering one row of 3 cells in FW and HW. Anal loop with 13-14 cells. Anal loop and posterior wing margin separated by 2 rows of cells except on left wing where posterodistal part of anal loop is separated by one cell from wing margin.

Abdomen. Penis almost identical to that of holotype except for the remarkable presence of a third short, very thin and somewhat straight flagellum having its base close to right side of the base of strong median flagellum (Fig. 4B-D, see text below). Epiproct reaching basal $\% / 10$ of the cercus length [this distinct difference with holotype is very probably due to the strong and probably artificial bent of S10, compare Fig. 3B with Fig. 4E].

\section{Description of the $S 7$ pilose complex (Fig. 4F)}

Presence at distal $6 / 10$ of the sternite of a kind of large tubercle bearing long, straight and caudad directed setae implanted on postero-dorsal surface. This tubercle connected to 4 carinae: 1) an anterior one occupying about $1.5 / 10$ of the sternal length and strengthening distally; 2) two lateral ones, weak and slightly oblique and bearing on posterior margin a row of caudad directed setae decreasing in length toward lateral extremities; and 3) a posterior one well defined on about $0.5 / 10$ of sternal length and distally progressively weakening to a rounded fold before vanishing. At about distal 8/10 of sternite presence of a transversally elongated low subtriangular tubercle of granular aspect (insertion of setae) delimited anteriorly by a thin transversal groove and bearing long, straight and caudad directed setae. Pleural membrane at level of distal pilose tubercle, with a brush of long straight medio-caudally directed setae. 


\section{Comparison of the vesicae spermalis}

The penis of the two specimens are almost identical except for the presence in the paratype of an additional third small flagellum placed between the two usual ones. This flagellum appears more cylindrical in ethanol and its bifid apex is hardly visible, once dried it appears, as the other flagella, somewhat flattened, and the bifid apex appears more clearly (Fig. 4B). The presence of a third flagellum within the genus was never reported before. Its unique presence in the paratype is remarkable and somewhat mysterious. As the paratype seems to be a submature (penis less sclerotized, wings less tinged, and body colors less pronounced), we assume that this small flagellum could be cut by autotomy during mating and could prevent sperm removing by other males. It is also possible that this flagellum is the result of a teratologic or atavistic process (the sister genus Metaphya Laidlaw, 1912 exhibits five processes at apex of the penis, see remark 1 below). Complementary study and more material are needed to try to answer to this riddle.

Paratype measurements $(\mathrm{mm})$. Total length (including anal appendages) 39.5, FW length 28.0, HW length 26.5 (estimation, post-Pt missing), FW pterostigma 1.8 (at $\mathrm{C}$ and RA veins), HW pterostigma 1.75 (at $C$ and $R A$ veins), pro/ meso-/metathoracic legs length (including coxa and trochanter) - (incomplete)/12.7/15.5, metatibia length 5.6, abdomen length (including anal appendages) 27.0, superior anal appendages (cerci) 1.9, inferior anal appendage (epiproct) 1.7, abdomen width at S2 2.4, at median part of S4 (minimal width) 1.1, at posterior margin of S7/anterior margin of S8 2.8 (maximal width).

\section{Species Key to males NAVICORDUlia Machado \& Costa, 1995}

The core of this key is based on the work Machado \& Costa (1995) and couplet five springs with little changes from Pinto \& Lamas (2010).

1. Cerci (superior appendages) long to very long 2.5-3.9 mm. Epiproct (inferior appendage) distinctly shorter than cerci. Distal half of cerci provided with a brush of long hairs directed dorsally, laterally or ventrally (Group longistyla)

- Cerci (superior appendages) short 1.6-2.0 mm. Epiproct (inferior appendage) almost as long to distinctly longer than cerci. Distal half of cerci without a brush of long hairs directed dorsally, laterally or ventrally (sparse setae present) (Group errans)

2. Cerci in lateral view with a distinct median dorsal large concavity occupying about $2 / 10$ of the length of the cerci followed distally by a long convexity occupying about $1 / 2$ of the length of the cerci. Length of cerci $>$ $3.5 \mathrm{~mm}$ N. tumucurakensis Fleck, 2017

- Cerci in lateral view without distinct median dorsal large concavity followed distally by a long convexity. Length of cerci $<3.5 \mathrm{~mm}$

3. Cerci in lateral view with the proximal carinated part distinctly longer than the distal non-carinated one, in dorsal view with a distinct external concavity at the distal third. Genital lobe triangular ..... N. nitens (De Marmels, 1991)

- Cerci in lateral view with the proximal carinated part about as long or distinctly shorter than the distal noncarinated one, in dorsal view without distinct external concavity. Genital lobe quadrangular

4. Dorso-basal tubercle poorly developed and ventrolateral tubercle vestigial to absent. Ventro-medial tubercle visible in dorsal view. Maximum width of abdomen between S7 and S8 2.3-2.4 mm [Distrito Federal in Brazil] N. longistyla Machado \& Costa, 1995

- Dorso-basal and ventro-lateral tubercles developed, the latter partially visible in dorsal view. Ventro-medial tubercle poorly developed, not visible in dorsal view. Maximum width of abdomen between S7 and S8 2.8-3.0 mm.... 5

5. Cerci in lateral view with carinated part as long as the non-carinated (ratio of carinated part / total length of cercus $c$. 0.48). Cerci slightly longer than epiproct (ratio between epiproct / total length of cercus $\geq 0.77$ ). Postfrons with metallic green reflections similar to that of thorax [Minas Gerais State in Brazil]

N. kiautai Machado \& Costa, 1995

- Cerci in lateral view with carinated part distinctly shorter than non-carinated (ratio of carinated part / total length of cercus $\leq 0.33$ ). Cerci distinctly longer than epiproct (maximum ratio between epiproct / total length of cercus c. 0.62). Postfrons with metallic blue reflections differing from largely metallic green thorax [Santa Catarina State in Brazil] N. aemulatrix Pinto \& Lamas, 2010

6. Cerci in lateral view with a large basal ventral tooth N. pascali n. sp.

- Cerci in lateral view without basal ventral tooth 7

7. Epiproct distinctly longer than cerci N. mielkei Machado \& Costa, 1995

- Epiproct about as long as cerci or slightly shorter 
8. Cerci with ventro-lateral tubercle. Genital lobe triangular or quadrangular ........................................... 9

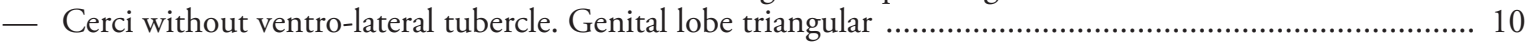

9. Proximal carinated part of cerci four times as long as the distal non-carinated one. Genital lobe triangular .... N. vagans (De Marmels, 1991) - Proximal carinated part of cerci twice as long as the distal non-carinated one. Genital lobe quadrangular .......

10. In lateral view non-carinated part of the cerci slightly larger than carinated part. Ventral margin of carinated part concave in lateral view. Costa brown N. errans (Calvert, 1909)

- In lateral view non-carinated part of the cerci slightly narrower than carinated part. Ventral margin of carinated part straight in lateral view. Costa white N. leptostyla Machado \& Costa, 1995.

\section{DISCUSSION}

\section{COMPARISON WITH OTHER SPECIES AND AFFINITIES}

The new species belongs without doubt to the genus Navicordulia by its relative small size, by the typical wing venation with noteworthy the excavation of the male anal angle, by the male ventral abdominal pilose complex present on the $S 7$ and $S 8$ and by the typical shape of the hamule.

For practical taxonomic reasons apparently not related to phylogenetic considerations, Machado \& Costa (1995) divided the genus Navicordulia into two groups of species based on characters of male caudal appendages: the longistyla-group having very long cerci (2.5-2.9 mm), epiproct distinctly shorter than cerci, and distal half of cerci provided with a long fringe of long hair-like setae directed dorsally or laterally; and the errans-group having short cerci (1.6-2.0 mm), epiproct almost as long to distinctly longer than cerci, and distal half of cerci without a fringe of long hair-like setae directed dorsally or laterally. The longistyla-group includes $N$. aemulatrix Pinto \& Lamas, 2010, N. kiautai Machado \& Costa, 1995, N. longistyla Machado \& Costa, 1995, N. nitens (De Marmels, 1991), and N. tumucurakensis Fleck, 2017. The errans-group includes $N$. atlantica Machado \& Costa, 1995, $N$. errans (Calvert, 1909), N. leptostyla Machado \& Costa, 1995, N. mielkei Machado \& Costa, 1995, and N. vagans (De Marmels, 1989). Two species, N. amazonica Machado \& Costa, 1995 and $N$. miersi Machado \& Costa, 1995, both known only by a single female specimen, cannot be attributed to either group.

Following the classification of Machado \& Costa (1995), $N$. pascali n. sp. can be considered belonging to the errans-group despite an epiproct not "almost as long to distinctly longer than the cerci" (see also general remarks below).

The new species can readily be separated from all known males of the genus by two unique characters:

1) Cerci with a large ventral basal tooth. These structures are not homologous to the lateral tubercle sensu Machado \& Costa (1995), because the lateral tubercle sensu Machado \& Costa (1995) systematically appears at distal end of the lateral carina; the original diagnosis must be amended and the original character "Male superior appendages (= cerci) without a basal tooth" must be removed since in contradiction with the present study;
2) Distal end of the distal lateral carina not separating a basal ventral concave part, which is not rounded in cross section (= proximal part sensu Machado \& Costa [1995]), and a distal convex or straight part, which is rounded in cross section (= distal part sensu Machado \& Costa [1995]). It must be noted that in $N$. pascali n. sp. the proximal part ends distally close to the mid length of the second lateral carina, contrary to all other known males, where the distal end of the lateral carina exactly delimits the two structural parts of the cercus.

The S7 pilose complex seems to be also unique, presenting a large proximal median tubercle at the confluence of the four short carinae and a distal transversal triangular tubercle/ridge not connected to the distal carina.

The new species can be separated from species only known by females by a set of characters currently considered also present with little change in the male:

- From $N$. amazonica: 1) color of the head, except eyes, entirely orange in $N$. amazonica (including occiput) vs orange, brown and dark brown in $N$. pascali n. sp. (occiput dark brown); 2) third tarsal segment reddish brown vs dark brown to black as other tarsal segments; 3 ) number of rows of cells between anal loop and wing margin: 3 in $N$. amazonica vs 2 in $N$. pascali n. sp. (1 in left HW of paratype); and 4) length of legs: "short legged" species with hind legs including coxa c. $13.1 \mathrm{~mm}$ (Machado pers. com.) vs "rather long legged" species with hind leg including coxa $15.5 \mathrm{~mm}$.

- From $N$. miersi: 1) pterostigmata length: FW: $2.4 \mathrm{~mm}$ in $N$. miersi vs $1.8 \mathrm{~mm}$ in $N$. pascali n. sp.; HW: $2.3 \mathrm{~mm}$ in $N$. miersi vs $1.75 \mathrm{~mm} N$. pascali n. sp.; and 2) number of crossveins in both HW submedian spaces: 2 in $N$. miersi which is unique within the genus, vs 1 in $N$. pascali n. sp. It must be noted that $N$. miersi from southern Brazil and $N$. pascali n. sp. are separated by more than $2300 \mathrm{~km}$ giving a supplementary argument in favour of non conspecificity.

Even if character polarizations need to be confirmed by a larger study (we have used the genus Metaphya and the clade Aeshnosomata as outgroups, see general remarks below), $N$. pascali n. sp. is probably closely related to $N$. errans and $N$. leptostyla, as shown by the presence of: 1) a penis of type B or B' (see remark 1 below); 2) cerci with two lateral carinae, a short one, at the base of the cercus forming the oblique ventral margin at the largest part of the cercus, and a longer one, running along the longitudinal axis of the cercus 

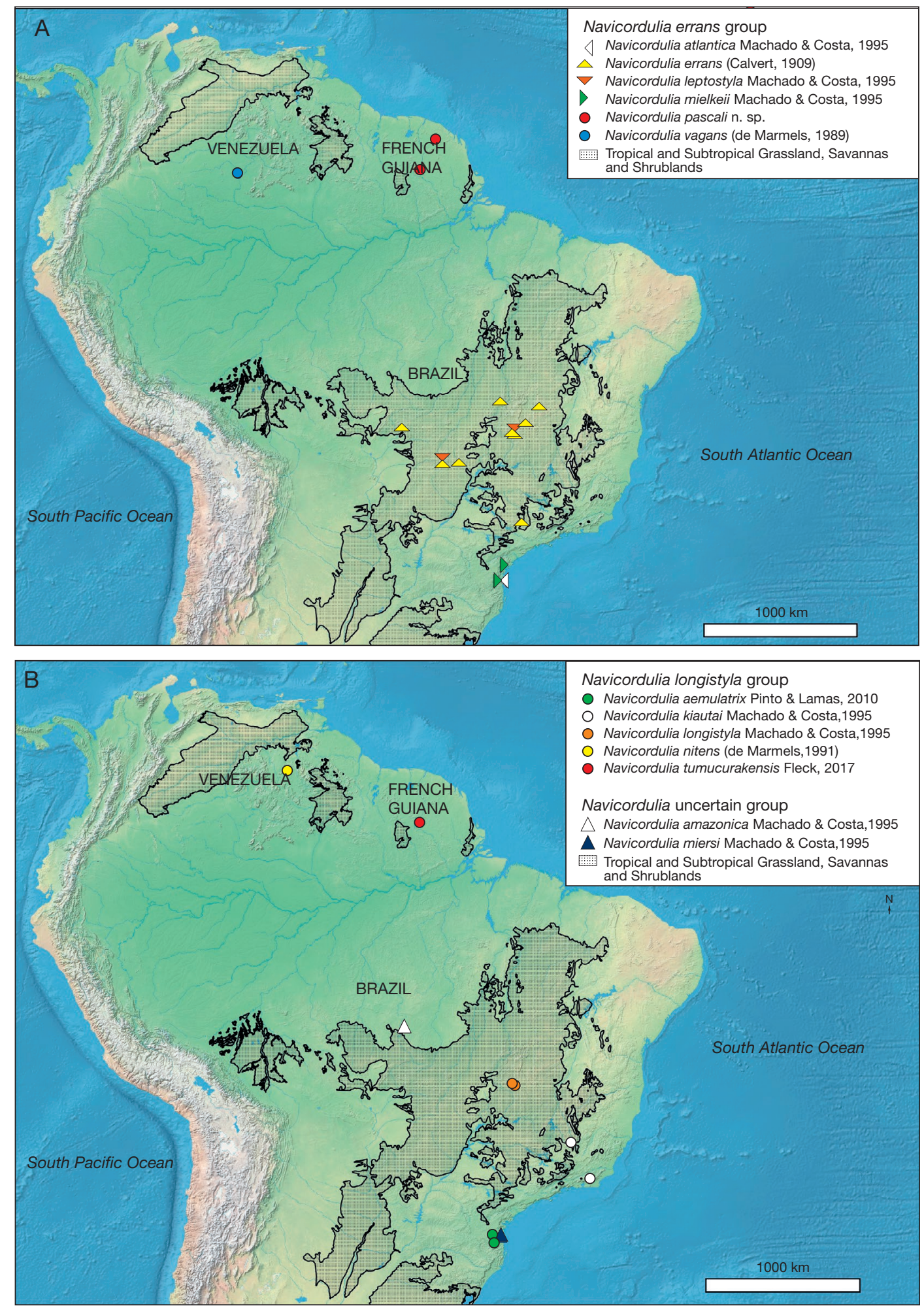

FIG. 5. - A, distribution map of Navicordulia Machado \& Costa, 1995 species of errans group and tropical today extension of grassland, savannah and shrubland in South America following The Nature Conservancy, terrestrial ecoregions. Map background: Natural Earth II; B, distribution map of Navicordulia species of longistyla and uncertain groups and tropical today extension of grassland, savannah and shrubland in South America following The Nature Conservancy, terrestrial ecoregions. Map background: Natural Earth II.

(see Machado \& Costa [1995]: fig. 16 and fig. 19, and see remark 2 below); 3) a S7 pilose complex with additional distal transverse ridge (see remark 3 below); and 4) a genital lobe triangular and caudad directed (see remark 4 below).
Characters (1) and (2) are apomorphic and characters (3) and (4) are only shared with $N$. vagans (De Marmels pers. com.; De Marmels 1989), making this last species the possible sister taxon of the errans-leptostyla-pascali-group. 


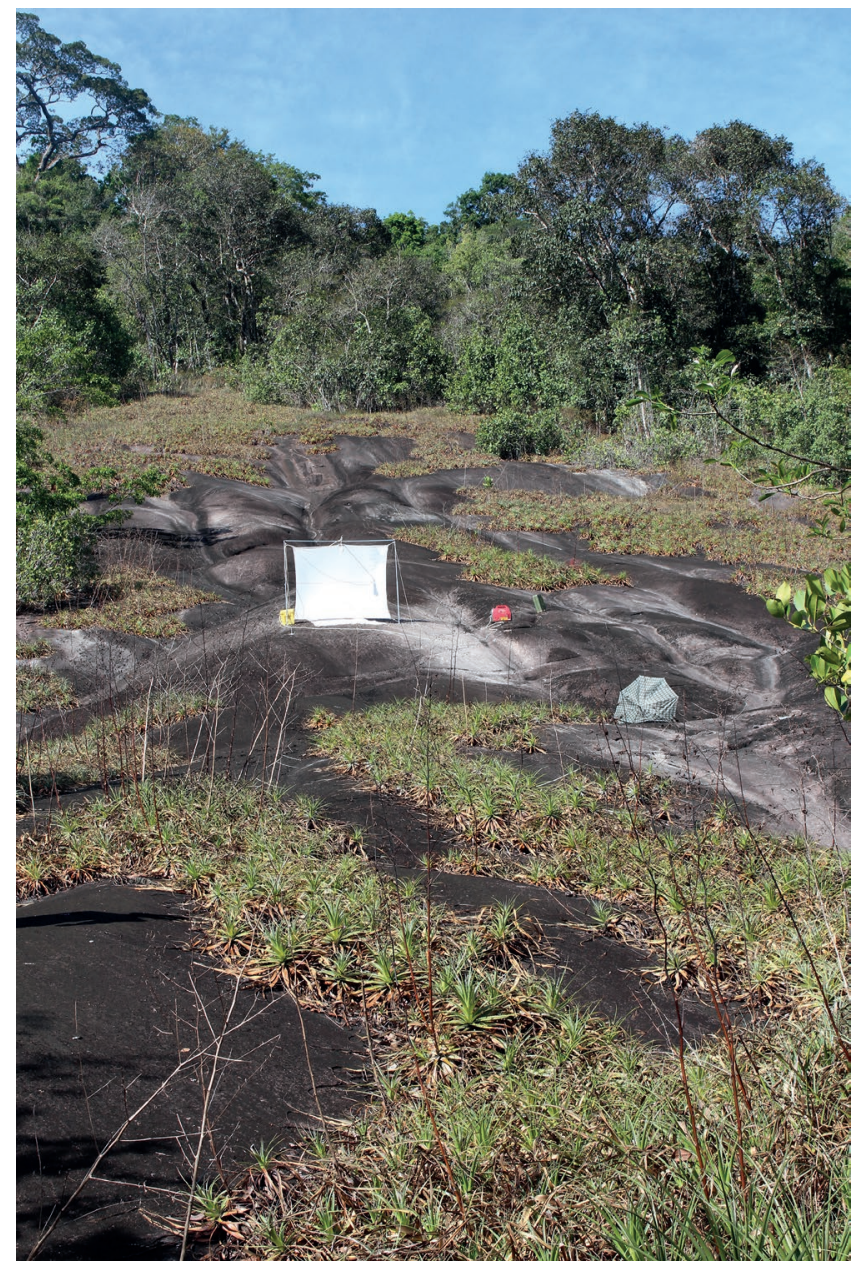

FIG. 6. - "Savane-roche" in the Barruol Mounts, locus typicus of Navicordulia pascali n. sp. Photo by Stéphane Brûlé.

It should be noted also that these four species do not have mesotibial keels within the errans-group. The genital lobe of $N$. nitens (of the longistyla-group) is not considered strictly homologous because, in spite of its grossly triangular form, it is apically largely rounded and its posterior margin is not caudad directed but ventrally directed (De Marmels 1991: fig. 6). The penis of $N$. pascali n. sp. is of B' type, which could be considered, following a gradualist transformation, as an intermediate stage between the A type with flagella subequal in length and strength and the B type with a very small right lateral flagellum and much larger and very long median flagellum. Considering the penis structure, this suggests that $N$. pascali n. sp. could be the sister species of a clade ( $N$. errans, $N$. leptostyla). Consequently, until a more complete phylogenetic study is made, $N$. pascali n. sp. can be considered to be the closest known relative to $N$. errans and $N$. leptostyla, two typical Cerrado (savannah) species found above $650 \mathrm{~m}$ (Machado \& Costa 1995) and distant of about $2000 \mathrm{~km}$ south from the French Guiana. Affinities with the Venezuelan $N$. vagans, a forest species found in lowland about $1400 \mathrm{~km}$ east from French Guiana are also very probable.
GENERAL REMARKS

1) The phylogeny of the Corduliidae s.str. remains to be established. Fleck $(2012,2017)$, demonstrated that Metaphya is the sister genus of Navicordulia, and that the clade Aeschnosomata (genera Aeschnosoma Selys, 1870, Libellulosoma Martin, 1907 and Pentathemis Karsch, 1890) is the sister group of remaining Corduliidae s.str. Thus we have chosen as closely related outgroup the genus Metaphya and as rather more distant outgroup the Aeschnosomata.

The penis of "Corduliidae" is very variable from one species to another, and generally one penis is able to "define" one species. Penes appear rather similar, with little differences, only in closely related species. Thus a penis of Corduliidae (or even that of many groups of Anisoptera) should be regarded as a kind of fingerprint for which polarization of characters is often not possible due probably to high rate of evolution of this structure and ephemeral intermediate forms between two taxa.

The apex of penis of Metaphya presents five expansions, one long flagellum and four spiny cornua of different length (Fleck, unpublished) totally different from the structures observed in Navicordulia.

Apex of the V4 of penes of Aeschnosomata is extremely variable, and can appear without any flagellum, or with one long flagellum, or with one short and thick flagellum (furthermore medio-ventral, not apical; Fleck, unpublished), or with two flagella and a kind of small cornu (one flagellum each side of the sagittal axis, then different to the state observed in Navicordulia), or with two very ill defined and short pellucid flattened membranous symmetrical expansions (Fleck, unpublished). Using these outgroups and taking into account the preliminary remark, in the current knowledge of the Corduliidae s.str. phylogeny, the character states of outgroups is different from that of ingroup and we have therefore considered each state of the penis structure of Navicordulia derived. In addition we can admit that the more asymmetric the penis, the more derived. Indeed penes of Libellulidae Leach, 1815, Aeshnoidea Leach, 1815, Gomphoidea Rambur, 1842, Cordulegastroidea Hagen, 1875 as well as several incertae sedis genera sister groups of Corduliidae s.str. (like Gomphomacromia Brauer, 1864 or Lauromacromia Geijskes, 1970 among others) present a symmetric penis, thus when two flagella are present, they are symmetric along sagittal axis, and are generally of same length and strength. From this we can postulate that symmetric penis occurs in the groundplan of the Corduliidae s.str. and that asymmetries observed in members of this family are derived situations.

2) Aeschnosomata have no clear laterobasal carina (in some species a kind of very short ventral elongated bulged structure is visible at the extreme base of the cerci) and no distal carina, and Metaphya has only one latero-ventral carina at base of the cerci. Therefore we consider here two lateral carinae as derived.

3) A S7 pilose complex sensu Machado \& Costa (1995) is known only in Navicordulia and its sister genus Metaphya. The distal pilose structure in Metaphya is not a transversal ridge but a median small knob very similar to the one observed in $N$. tumucurakensis. We considered here a small median knob 


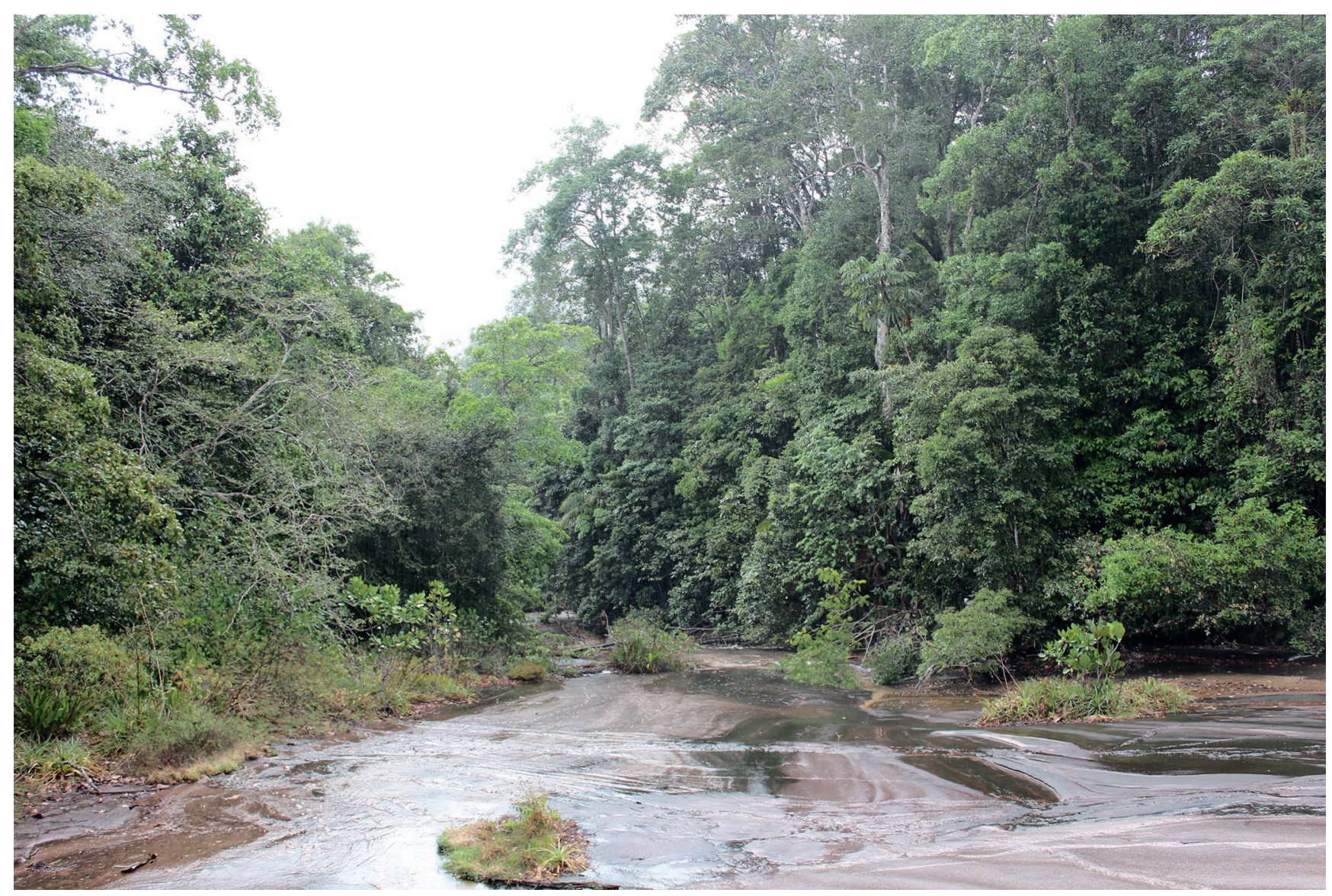

FIG. 7. - Rock-bottomed stream near locus typicus, Barruol Mounts. Photo by Stéphane Brûlé.

as plesiomorphic within this group, and we regard a transverse ridge as derived.

4) Aeschnosomata have a rounded genital lobe and are of little use here, in an interesting way Metaphya possesses a strong and subtriangular genital lobe rather similar to the ones observed in Navicordulia. It is long and clearly ventrally pointed and its posterior margin shows an inflection (as most species of Navicordulia except $N$. pascali n. sp., $N$. errans and $N$. vagans). We consider in this study a triangular and caudally directed genital lobe as derived.

\section{NOTES ON ECOLOGY AND BIOGEOGRAPHY}

The genus Navicordulia is mostly distributed in southeastern Brazil south of the Amazon forest (Fig. 5), with three species in Cerrado (savannah), five species in Atlantic forests and one species in Southern part of Amazon forest (Machado \& Costa 1995, Pinto \& Lamas 2010). Before the recent capture of $N$. pascali n. sp. and of $N$. tumucurakensis (Fleck 2017) in French Guiana, the genus was only known by two species in the Northern part of Amazon forest, in Venezuela (De Marmels 1989, 1991). Cerrado species seems not to be rare (Machado \& Costa 1995) and show the largest distributions (Fig. 5A). On the contrary, forest species are seldom captured and most only known by holotype or type series. This apparent rarity reflects probably more elusiveness than rarity (Fleck 2017, see also Fleck \& Neiss 2012). Conditions of captures of $N$. pascali n. sp., e.g. light trap in a "savaneroche" at the foot of an inselberg above plain forest for the holotype (Fig. 6) and canopy interception trap in "lowland" for the paratype, could confirm that imagoes of forest species mostly live in the canopy (Machado \& Costa 1995; Fleck 2017). Seasonality is also probably an important factor since all Guianan specimens (three males, and three undescribed females [Fleck and Juillerat, pers. obs.]) have been captured in March during rainy season.

Both specimens of Navicordulia pascali n. sp. were captured in upper drainage basins surrounded by inselbergs in central and southern French Guiana, the same habitat that for N. tumucurakensis (Fleck 2017). Inselbergs are dome-shaped crystalline rocky outcrops rising above surrounding plains. They are covered with discontinuous vegetation forming a type of mosaic of scattered herbaceous and shrubby patches separated by bare rock, locally called "savane roche" (Fig. 6) (Sarthou et al. 2017), a potential terrestrial habitat for Navicordulia pascali $\mathrm{n}$. sp. Inselbergs are mostly xeric habitats but can show seasonally water-filled aquatic habitats such as pools and temporary flush which may carry water for several consecutive weeks or months during rainy season (Porembski 2007). Moreover some rock-bottomed streams can develop at the base of inselbergs (Fig. 7). These kinds of streams 
could host Navicordulia larvae since the only known larva of the genus, who belongs $N$. nitens, has emerged from such a stream in the Tepui region of Venezuela (De Marmels 1991).

Navicordulia pascali $\mathrm{n}$. sp. most probably also occur in Amapá state of Brazil and in Surinam, as the Mitaraka Mounts encompass territories of the three countries, with similar habitats. Brazil and Surinam are thus only 3 and $13 \mathrm{~km}$ away from collecting site of the paratype.

The two groups of Navicordulia following Machado \& Costa (1995), the errans group (short cerci species) and the longistyla group (long cerci species), are both distributed over the whole range of the genus (Fig. 5). The two Guianese Navicordulia show closest affinities with species of the Cerrado, $N$. errans and $N$. leptostyla for $N$. pascali n. sp. and $N$. longistyla for $N$. tumucurakensis (Fleck 2017). Both are today distant about $2000 \mathrm{~km}$ from their closest known relatives. Some hypotheses suggest that savannahs have followed past climatic changes that occurred during Pleistocene and Holocene, with expansions during Glacial (dry) periods and regressions during Interglacial (moist) periods (Hooghiemstra \& van der Hammen 1998). Such kind of changes could also have occurred during the Tertiary following Haffer (2008). For example, convergent data integrate the southern plain of French Guiana within a large continuous savannah zone spreading from the Venezuelan Llanos, including Roraima, Rupununi, Sipaliwini savannahs to the upper and middle parts of the northern tributaries of the Amazon River during drier periods of the Holocene (Mayle \& Power 2008; Sarthou et al. 2017). Following these hypotheses, Cerrado dragonfly species could have dispersed during Glacial periods and been isolated during Interglacial periods, favoring speciation events. However other hypotheses argue that major diversification events occurred in the Tertiary well before Pleistocene (Colinvaux \& de Oliveira 2001). Recent molecular phylogenetic studies suggest that today neotropical biodiversity is the result of complex ecological and evolutionary trends initiated by Neogene tectonic events and paleogeographic reorganisations and is maintained by the action of Pleistocene climatic changes (Rull 2011). Each lineage has its own history and the strongest predictors of speciation are its duration in the landscape and the ability to disperse (Smith et al. 2014). As a long isolated lineage (Fleck 2017) diversified in different biomes, Navicordulia would be an highly interesting model to investigate.

\section{Acknowledgements}

Thanks to Pierre-Henri Dalens, Serge Fernandez and Stéphane Brûlé for collecting the holotype and for providing many interesting odonates from the interior of French Guiana.

The paratype was collected during the "Our Planet Reviewed" Guyane-2015 expedition in the Mitaraka range, in the core area of the French Guiana Amazonian Park, organized by the MNHN and Pro-Natura international. The expedition was funded by the European Regional Development Fund (ERDF), the Conseil régional de Guyane, the Conseil général de Guyane, the Direction de l'Environnement, de l'Aménagement et du Logement and by the Ministère de l'Éducation nationale, de l'Enseignement supérieur et de la Recherche. It was realized in collaboration with the Parc amazonien de Guyane and the Société Entomologique Antilles-Guyane (SEAG) which was in the field of great help (Pierre-Henri Dalens, Serge Fernandez and colleagues).

We also want to thank Angelo B. M. Machado for providing literature and data, Matthias Borer for his help with stacking photography, Stéphane Brûlé for his pictures of the type locality, Jürg de Marmels and André Nel for reviewing the manuscript and Marceau Minot for putting us in touch.

\section{REFERENCES}

BECHLY G. 1996. — Morphologische Untersuchungen am Flügelgeäder der rezenten Libellen und deren Stammgruppenvertreter (Insecta; Pterygota; Odonata), unter besonderer Berücksichtigung der Phylogenetischen Systematik und des Grundplanes der Odonata. Petalura, special volume 2, $402 \mathrm{p}$.

Colinvaux P. A. \& DE Oliveira P. E. 2001. - Amazon plant diversity and climate through the Cenozoic. Paleogeography, Paleoclimatology, Paleoecology 166: 51-63. https://doi.org/10.1016/ S0031-0182(00)00201-7

De Marmels J. 1989. - Odonata or dragonflies from Cerro de la Neblina and the adjacent lowland between the Rio Baria, the Casiquiare and the Rio Negro (Venezuela). I. Adults. Boletín de la Academia de las Ciências Físicas, Matemática y Naturales 25: 11-78.

DE MARMELS J. 1991. — Dorocordulia nitens sp. n., eine neue Smaragdlibelle aus Venezuela (Odonata: Corduliidae). Mitteilungen der Entomologischen Gesellschaft Basel 41: 106-111.

FLECK G. 2012. - Preliminary notes on the genus Aeschnosoma Selys, 1870 (Odonata: Anisoptera: Corduliidaes.s.). Annales de la Société entomologique de France 48 (1-2): 225-228.

FLeCK G. 2017. - Notes on the genus Navicordulia Machado \& Costa, 1995 (Odonata: Anisoptera: Corduliidae s. str.): description of a new species, phylogenetic affinities and aspects of biogeography. Zootaxa 4272 (2): 251-262. https://doi.org/10.11646/ zootaxa.4272.2.6

Fleck G., Bechly G., MartíneZ-Delclòs X., Jarzembowski E., Coram R. \& Nel A. 2003. - Phylogeny and classification of the Stenophlebioptera (Odonata: Epiproctophora). Annales de la Société entomologique de France (Nouvelle série) 39: 55-93. https://doi.org/10.1080/00379271.2003.10697363

FleCK G. \& NeISS U. G. 2012. - A new species of the genus Aeschnosoma Selys, 1870 (Odonata: Anisoptera: Corduliidae). Zootaxa 3159: 47-58. https://doi.org/10.11646/zootaxa.3159.1.3

FleCK G. \& Nel A. 2003. - Revision of the Mesozoic family Aeschnidiidae (Odonata: Anisoptera). Zoologica 153: 1-172.

GARRISON R. W., VON ELLENRIEDER N. \& LOUTON J. A. 2006. Dragonfly genera of the New World: an illustrated and annotated key to the Anisoptera. The John Hopkins University Press, Baltimore, xiv $+368 \mathrm{p}$.

HAFFER J. 2008. - Hypotheses to explain the origin of species in Amazonia. Brazilian Journal of Biology 68 (4): 917-947. https:// doi.org/10.1590/S1519-69842008000500003

Hooghiemstra H. \& VAN DER HAMmEN T. 1998. — Neogene and Quaternary development of the neotropical rain forest: the forest refugia hypothesis, and a literature overview. Earth-Science Reviews 44: 147-183. https://doi.org/10.1016/S0012-8252(98)00027-0

Machado A. B. M. \& CostA J. M. 1995. - Navicordulia gen. nov., a new genus of neotropical Corduliinae, with descriptions of seven new species (Anisoptera: Corduliidae). Odonatologica 24 (2): $187-218$

MaYle F. E. \& POWer M. J. 2008. - Impact of a drier EarlyMid-Holocene climate upon Amazonian forests. Philosophical 
Transactions of the Royal Society of London. Series B, Biological Sciences 363: 1829-1838. https://doi.org/10.1098/rstb.2007.0019

PfaU H. K. 2011. - Functional Morphology and Evolution of the Male Secondary Copulatory Apparatus of the Anisoptera (Insecta: Odonata). Zoologica 156: 1-103.

PinTo A. P. \& LAmas C. J. E. 2010. - Navicordulia aemulatrix sp. nov. (Odonata: Corduliidae) from northeastern Santa Catarina State, Brazil. Revista Brasileira de Entomologia 54 (4): 608-617. https://doi.org/10.1590/S0085-56262010000400012

PinTo A. P. \& Lamas C. J. E. 2011. - Description of the female of Navicordulia aemulatrix Pinto \& Lamas and additional notes on the male (Odonata: Corduliidae). Neotropical Entomology 40 (6): 698-703.

POREMBSKI S. 2007. — Tropical inselbergs: habitat types, adaptive strategies and diversity patterns. Revista Brasileira de Botânica 30: 579-586.

RULL V. 2011. - Neotropical biodiversity: timing and potential drivers. Trends in Ecology \& Evolution 26: 508-513.

Sarthou C., Pavoine S., Gasc J.-P., De Massary J.-C. \& Ponge J.-F. 2017. - From inselberg to inselberg: floristic patterns across scales in French Guiana (South America). Flora 229: 147-158. https://doi.org/10.1016/j.flora.2017.02.025

Smith B. T., McCormack J. E., Cuervo A. M., Hickerson M. J., Aleixo A., Cadena C. D., Pérez-Emán J., Burney C. W., Xie X., Harvey M. G., Faircloth B. C., Glenn T. C., Derryberry E. P., Prejean J., Fields S. \& Brumfield R. T. 2014. - The drivers of tropical speciation. Nature 515: 406409. https://doi.org/10.1038/nature13687

Touroult J., Pollet M. \& Pascal O. 2018. - Overview of Mitaraka survey: research frame, study site and field protocols, in TOuroult J., "Our Planet Reviewed" 2015 large-scale biotic survey in Mitaraka, French Guiana. Zoosystema 40 (13): 327 365. https://doi.org/10.5252/zoosystema2018v40a13. http:// zoosystema.com/40/13 